\title{
The Philosophical Aspects of the Dialogue between Modern Cosmology and Theology
}

\author{
Alexei V. Nesteruk ${ }^{1,2}$, Aleksandr V. Soldatov ${ }^{2}$ \\ ${ }^{1}$ University of Portsmouth, Portsmouth, UK \\ ${ }^{2}$ State Marine Technical University, St Petersburg, Russia \\ 凶soldatov2012@yandex.ru
}

\begin{abstract}
Introduction. The paper deals with the philosophical problems of the modern dialogue between cosmology and theology. It is argued that no existential contradiction is possible between them as originating in one and the same human condition. The difference between cosmology and theology amounts to the difference in their open-ended hermeneutics of the outer world. It is from within this philosophical conclusion that the hot issue of the dialogue are discussed and some insights are proposed.
\end{abstract}

Methodology and sources. The philosophical analysis is based on the discussion of epistemological issues in modern cosmology and their relevance to theological view of the world. The method is similar to existential phenomenology's approach to the constitution of the notion of the universe in cosmology and theology as an open-ended hermeneutics of the world.

Results and discussion. It is shown that no existential contradiction is possible between two types of hermeneutics as originating in one and the same human condition. It is human being that becomes the major theme of the dialogue between cosmology and theology.

On the basis of the conclusions made the paper discusses some "hot" issues in the contemporary cosmology-theology discussion, including: 1) The inseparability of cosmology and theology in justification of the possibility of cosmological knowledge, 2) Fine-tuning, Anthropic principle, fitness of the universe for life, 3) The unknowability of the universe and apophaticism in cosmology, 4) Multiple universes and their ontology, 5) How much of life is in the universe: the Search for Extraterrestrial Intelligence (SETI), exoplanets and theological consequence for multiple incarnations, 6) The origin of the universe in modern scientific cosmology and its relevance to the theologically understood creatio ex nihilo, 7) Consciousness and the universe: can cosmology account for its own possibility without appealing to the theologically understood human capacity in producing an intellectual synthesis of the universe.

Conclusion. On the basis of the methods applied to the hot issues in the dialogue between cosmology and theology one concludes that the dialogue between cosmology and theology is an open-ended enterprise related to the fundamentally concealed origins of humanity and universe. The difference is hermeneutics of the universe does not create any contradiction or tension but reflects a dualistic position of humanity in the universe, being an insignificant part of it and at the same time its center of disclosure and manifestation.

Key words: cosmology, history, humanity, phenomenology, philosophy, theology, universe.

For citation: Nesteruk, A. V., Soldatov, A. V. The Philosophical Aspects of the Dialogue between Modern Cosmology and Theology. DISCOURSE. 2021. vol. 7, no. 5, pp. 55-70. DOI: 10.32603/24128562-2021-7-5-55-70

(c) Nesteruk A. V., Soldatov A. V., 2021

Контент доступен по лицензии Creative Commons Attribution 4.0 License.

This work is licensed under a Creative Commons Attribution 4.0 License. 
Source of financing. Alexei Nesteruk acknowledges the support for this work through a participation in the project "Science and Orthodoxy around the World" run by the National Hellenic Research Foundation in Greece and sponsored by the World Charity Templeton Foundation, as well as through the grant "PH Philosophy In Neopatristics: New Figures And New Interpretations" from The National Science Centre, Poland (DEC-2018/31/B/HS1/01861).

Conflict of interest. No conflicts of interest related to this publication were reported.

Received 21.09.2021; adopted after review 08.10.2021; published online 24.11.2021

\title{
Философские аспекты диалога между современной космологией и теологией
}

\author{
A. В. Нестерук ${ }^{1,2}$, А. В. Солдатов ${ }^{2 \bowtie}$ \\ ${ }^{1}$ Университет Портсмута, Портсмут, Великобритания \\ ${ }^{2}$ Санкт-Петербургский морской технический университет, Санкт-Петербург, Россия

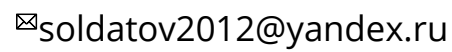

Введение. В статье рассматриваются философские проблемы диалога между современной космологией и теологией. Приводятся аргументы в пользу того, что не существует экзистенциального противоречия между двумя взглядами на природу Вселенной, поскольку оба происходят из одного и того же человеческого состояния. Различие между научной космологией и теологическим воззрением на природу космоса происходит из различия в герменевтике опыта существования в мире. Исходя из этого философского вывода обсуждаются некоторые «горячие» проблемы диалога между космологией и теологией и предлагаются пути их интерпретации

Методология и источники. Философский анализ основан на обсуждении эпистемологических проблем современной космологии и их релевантности для теологической картины мира. Используемый метод аналогичен подходу экзистенциальной феноменологии в отношении конституирования концепции Вселенной в космологии и теологии как нескончаемой герменевтики мира.

Результаты и обсуждение. Показано, что не существует экзистенциального противоречия между двумя типами герменевтики, поскольку человек становится центральной темой диалога между космологией и теологией. Исходя из сформулированных выше тезисов, статья обсуждает ряд «горячих» проблем в современном диалоге между космологией и теологией, включая: 1) взаимодополнительность космологии и теологии в обосновании возможности знаний о Вселенной; 2) точную настройку космологических параметров для возможности жизни во Вселенной и антропный принцип; 3) непознаваемость Вселенной и апофатизм в космологии; 4) проблему множественности вселенных и их онтологический статус; 5) жизнь во Вселенной: поиск внеземного разума (SETI), открытие экзопланет и теологические последствия для множественных воплощений; 6) происхождение Вселенной в современной научной космологии и соотношение теорий этого происхождения с теологически понимаемым creatio ex nihilo; 7) сознание и Вселенная: может ли космология обосновать факт своей собственной возможности без обращения к теологически понимаемой способности человека в осуществлении интеллектуального синтеза Вселенной.

Заключение. На основе философских методов, примененных к «горячим» проблемам в диалоге между космологией и теологией, можно заключить, что диалог является нескончаемой попыткой преодолеть принципиальную сокрытость происхождения человека и Вселенной. Различие в герменевтике Вселенной в космологии и теологии 
не порождает экзистенциального противоречия или напряжения, а отражает дуалистическое положение человека во Вселенной, который является, с одной стороны, ее незначительной частью, а с другой стороны, центром ее раскрытия и манифестации.

Ключевые слова: Вселенная, история, космология, философия, феноменология, теология, человек.

Для цитирования: Нестерук А. В., Солдатов А. В. Философские аспекты диалога между современной космологией и теологией // дИСКУРС. 2021. T. 7, № 5. C. 55-70. DOI: 10.32603/2412-85622021-7-5-55-70.

Финансирование. Нестерук А. В. выражает благодарность за финансовую поддержку, происходящую из участия в проекте «Science and Orthodoxy around the World», руководимом Национальным греческим научным фондом и спонсируемым Фондом Темплтона, а также из участия в гранте «РH Philosophy In Neopatristics: New Figures And New Interpretations» Национального научного центра в Польше (DEC-2018/31/B/HS1/01861).

Конфликт интересов. О конфликте интересов, связанном с данной публикацией, не сообщалось.

Поступила 21.09.2021; принята после рецензирования 08.10.2021; опубликована онлайн 24.11.2021

Introduction. The issue of cosmology and theology is a perennial one and this is the reason why we will have to appeal to some historical references. But being a perennial issue, it also requires a new philosophical insight on the sense of why this issue is still actual and will not go away in the foreseeable future. Thus first we proceed methodologically with setting the boundaries and methods of that which we are going to discuss by making a general conclusion on the relevance of theology to cosmology. Then, as case studies, we will apply our conclusions to some particular "hot" issues in the dialogue between cosmology and theology in order to bring them to a new philosophical elucidation.

Methodology and sources. First of all, let us discuss terminology in order to understand the meaning of the enquiry about the relevance of theology for cosmology. The distinction and difference between three basic terms cosmology, philosophy and theology is important because it is related to the present historical period when that which is implied by these terms was not always in history. The main question is the sense of what is meant by cosmology and, correspondingly, if we enquire about the relevance of theology to cosmology, what is meant by cosmology in this question. Modern researches in the field of physical cosmology, when they attempt to think of their discipline in a wide historical, social and philosophical context sometimes feel that there a distinction must be made between proper scientific aspects of cosmology (related to observations and mathematical models which aim to produce a credible and coherent account of the physical reality), and cosmological hypotheses which do not fall in the scope of scientific rationality. This happens when physical and mathematical hypotheses are produced with respect to that which is fundamentally unobservable. In this case philosophical ideas (and may be even theological motives) infiltrate cosmology. A typical example is a spectrum of models related to the origination of the universe ("creation" of the universe), as well as hypotheses of the so called multiverse (plurality of worlds). Another example is the famous Anthropic Principle (AP) which in all its varieties witnesses to the inference which does not have an intrinsic physical necessity and "observable" only through researcher's intentionality sometimes motivated by philosophical concerns. In all these issues cosmology is imbued with a wider system of ideas related to philosophy. These aspects of cosmology, in contradistinction to the physical cosmology, can be 
called philosophical cosmology, metaphysical cosmology (meta-cosmology [1, pp. 47-50]) or simply cosmologia [2, p. 4] a Greek word denoting cosmology as a part of philosophia (love for wisdom) and general knowledge (episteme).

Then the question present in the title of this article must be clarified: is theology relevant to physical cosmology, or to philosophical or meta-physical cosmology, or to cosmologia? In order to give an answer to this question one needs to adopt a kind of the overseeing position in order to relate these varieties of cosmology to theology as if one was able to encompass in thought both of them. Such an endeavour is possible either along the lines of reflecting upon the history of cosmological ideas thus seeing cosmology as an ongoing hermeneutics of the world. The weakness of this position is that it is historically contingent and thus purely empirical not clarifying the sense of the initial split in two classes of phenomena of the world related to cosmology and theology. In order to avoid such a contingency one needs to adopt a radical philosophical attitude by suspending a historical judgement and attempting to look at the relationship between all varieties of cosmology and theology from some apodictic grounds. These grounds can be either metaphysical (appealing to some a-priori models of reality) or existential (phenomenological) placing man at the center of disclosure of the universe, as well as of experience of God. Modern philosophy advocates "the end of metaphysics" in the sense that no ontology preceding that one which is asserted in cosmology or theology is possible (one of the arguments is that one cannot produce any realistic model of humanity by abstracting from its specific and concrete position in the universe as well as from its radically unknowable essence asserted by theology). Correspondingly it seem to us that the most realistic approach to the mediation between theology and cosmology is based on a simple empirical ground that both theology and cosmology manifest human activities having one single source, that is, human conscious life. Then the enquiry into the sense of the relevance of theology to cosmology turns out to be a rather trivial philosophical enquiry into the sense of the split between two phenomenalities of the human existence related to two types of experience of this existence.

If, for a second, one narrows cosmology to its modern scientific standing, then the issue of "cosmology and theology" could be qualified as non-scientific. There is no logical or any theoretical necessity in carrying out such an investigation. Scientific cosmology functions with no regard to either philosophy and theology. Correspondingly, whatever it claims about the whole physical universe remains within its own limits. However, if cosmology attempts to generalise its findings towards the whole being (understood either philosophically as the totality of existence or, theologically, as creation), it trespasses its own boundaries and thus ceases to function as a strictly scientific discipline. The scientific cosmology transforms in this case into a philosophical cosmology, or just into a sort of world outlook in the style of the ancient Greek cosmologia. Then all its edifice turns out to be non-descriptive, that is simply hermeneutical, where such a hermeneutics (as produced eidetically, on the level of some intentionality) is related to the hermeneutics of the human condition. Since the latter is the subject matter of theology, the mediation between cosmology and theology becomes inevitable. The transition from the scientific cosmology to the philosophical one corresponds to the transition from the objectivised order of the cosmos to its particular version disclosed from within the order of history. The extent of objectivity of the order of the cosmos is diminished simply because it is placed within the universally subjective order of humanity. Once again, the cosmic hermeneutics turns out to be an expressed outwardly hermeneutics of the human condition. 
The same thing can be said about theology. If the latter shifts its concern from the order of history (related to humanity's relations with God) towards the structure of the world as if theology makes some descriptive propositions about ontology of the world, it also transcends its capacity because effectively it attempts to predicate something about God and his creation which are both incommensurable with a finite human being (even made in the divine image). If theology is apophatic with respect to its truth claims about God, it should be apophatic to the same extent with respect to world and man himself as made by the infinite and incomprehensible Creator (on the general definition of apophaticism in knowledge as non-exhaustiveness of its object in terms of its signifiers see [3, p. 84]). Theology can disclose the sense of the Creator's presence in the world, but it cannot exhaust the sense of the world as the latter is presented to God himself. This follows simply from the fact that the world is contingent. One can enquire into the "what" of creation, but not of its "why." The order of history is human order. Therefore the order of humanity unable to know itself, being transferred to the whole world makes the cosmic order unknowable to the same extent as humanity itself. The cosmic order then becomes another form of a theological hermeneutics whose sense cannot have ultimate ontological foundations because they are concealed from humanity. One comes to a similar conclusion as it was made above that the theological hermeneutics of the created world is implicitly a hermeneutics of the worldly human condition in communion with God.

It becomes clear that the mediation between cosmology and theology is something which by definition exceeds a scientific, as well as strictly theological scope. In other words, if cosmology deals with the order of the cosmos, whereas theology deals with the order of history, the question of their interaction/mediation/dialogue becomes by its constitution a philosophical question about the hierarchy of these orders in human consciousness. The problem of relation between theology and cosmology turns out to be a philosophical problem of the paradoxical enclosure of these orders one into another. Indeed, on the one hand the order of history is enclosed into the cosmic order as the necessary condition of the former. On the other hand the very cosmic order is disclosed and articulated from within the order of history. The premise of man's existence as a theologian is its cosmic place, whereas man's premise of being a cosmologist is its Divine image. Cosmology and theology become inseparable if these disciplines pretend to realistically contribute to the description of the human condition. As to the descriptive statements about the external world in cosmology and theology, they acquire either a philosophical sense in the style of cosmologia of ancient Greeks, whereas theology becomes at best theologia naturalis. The interaction between the latter is ever historically contingent without clarifying the source of the paradoxical phenomenality of the order of the cosmos and the order of history.

Before going in detail into philosophical aspects of mediation between theology and cosmology one must admit that modern cosmology considered within modern culture becomes a sort of public "theology" [4, p. 46]. Contemporary cosmologists are often seen as exercising a certain priestly role in modern society [5] as if cosmological ideas had immediate existential and social impact which would catch and fascinate public opinion [6]. Then it is naturally that this "new cosmic theology" enters into the polemic with the traditional theology. The latter cannot abstain from this engagement because it must defend its convictions, but by so doing traditional theology itself engages not so much into the polemics on the nature of scientific claims about reality but into a polemics on a particular social and cultural (sometimes explicitly atheistic; see, 
for example, $[7,8]$ ) appropriation of cosmological theories. The public nature of cosmology means that it contributes to the overall human culture by supplying the latter with a grandiose multifarious narrative some parts of which are based on interpretations of observations and mathematical modelling. In such a public appropriation cosmology is subjected to a hermeneutics exceeding the scope of the scientific. However, if theology is aware of the fact that any hermeneutics of creation is historically contingent, science can hardly accept this because the latter implicitly follows a belief that any of its ideas expressed mathematically corresponds to reality in itself independently of how such a knowledge was obtained.

Philosophy and theology are prepared to accept the public nature of cosmological knowledge in the form of the constantly renewing narrative about the universe. This narrative includes up-todate scientific discoveries and ideas, as well as many trans-scientific extrapolations and speculations which exemplify the open-ended status of any scientific enquiry. It is not difficult to grasp that such a narrative leaves a strictly scientific field transforming scientific cosmology into cosmologia as part of the overall concept of reality. The ambitions of such a cosmology to provide a descriptive representation of reality have even less grounds than scientific hypotheses themselves. Since in such a narrative the notion of the universe accessible to the scientific grasp is transformed into the totality of being, infinite by definition cosmology loses its scientific status. Cosmology of the practically (and potentially) infinite universe cannot be ever accomplished and exhausted because of some fundamental physical and epistemological limits of the human knowledge of the universe [2]. In this trivial sense cosmology picturesquely provides one with an example of the open-ended hermeneutics of the large-scale physical existence (as that background which is necessary for existence of humanity). This hermeneutics itself has its own limits because it must comply with the physical laws (expressed mathematically) accessible to man in its constitution determined by these laws. This this hermeneutics is open-ended but yet limited by the horizon of the cognitive faculties of man in the conditions of corporeal existence. Here an analogy comes to mind with the apophatic sense of theology as admitting any possible hermeneutics of the infinite and incomprehensible Divine within the dogmatic definitions.

Can then the issue of the relevance of theology to cosmology become a question of a possibility of using a theological hermeneutics of creation together with the cosmological hermeneutics in order to produce a unified, more solid representation of one single whole, although open-ended? This question is a legitimate one because it has precedents in history, where cosmology was naturally a part of philosophy understood as knowledge, as well as theologia (understood as "knowledge of gods"). Here one can pose a question whether we return to posing a question on the relation between theology and cosmology as a historically contingent comparison of narratives related to modern era? Our objective was to avoid such an approach by transferring the question into an apodictic, that is philosophical frame. To formulate the sense of the "dialogue" between theology and cosmology as a comparison of two hermeneutics' of the world and to stop there is not philosophically deep. The question is why there are two hermeneutics but not one. This question brings any researcher back to the enquiry about the basic difference in the human condition of two types of experience: religious and natural (worldly). But this is a philosophical question so that the approach to the problem of a relation between theology and cosmology must be philosophical.

Indeed, in order to make a comparative analysis of two spheres of the human experience one must have an a-priori philosophical predisposition which is initiated not through the necessities of 
the scientific advance, not socio-historical factors, but through the logical necessity to understand how two types of experience of the universe are possible in one and the same human being. This philosophical concern shifts the center of enquiry from its objective pole (that is from truth claims about objective reality) to the subjective (noetic) pole by bringing on board an anthropological (existential) dimension of the problem. From within this dimension it seems that the question of the relevance of theology to cosmology or vice versa does not have too much sense, because it is the same as to ask what psychological experience of the universe is more relevant: the scientific one or that of theology?

Here the word relevance becomes inappropriate because both experiences are possible in human life and both do not contradict each other if one does not undertake their transmission into truthclaims. This entails that the enquiry into the interaction between cosmology and theology in one and the same human being is constitutive for man himself. This can be expressed in a different way: the disclosure and manifestation of the universe as it is studied in cosmology and asserted in theology is intrinsically linked to the existential desire to explicate the human condition, human life as it is experienced in its immediate givenness to every human being. Here cosmology represents a certain telos (goal) of the human intellectual activity in order to exercise, in words of the founders of phenomenology, "worldification" or "enworlding," whose scope is not reduced only to curiosity and wonder of the infinite sky and the cosmos, but is implanted in the very essence of the human telic constitution. From within such a vision of cosmology a particular historical distinction between that in cosmology which is strictly scientific (as defined at this particular moment) and that which represents a much wider narrative has only a historical significance, implying that those perennial issues which humanity encountered at the dawn of its conscious existence, such as, for example, the sense of contingent facticity of all, the origin of the universe and life in it, etc. remain undisclosed and concealed in spite of their ongoing scientific hermeneutics.

In spite of the fact that the ultimate origin of this concealment cannot be elucidated either scientifically or philosophically it can be interpreted anthropologically, that is as related to the most immediate existential anxiety of the origin of the human life. Here one sees a different approach to cosmology not as to a discipline which explores something out there (that is produces some descriptive claims about reality of things) but as to some outward expression of the human existence considered as a primary philosophical fact. The scheme "the universe therefore human existence" is replaced by a phenomenologically explicated existential formula "human existence therefore the universe", where in the former the universe is treated as a necessary background for the appearance of embodied consciousness, whereas in the latter the universe is treated as a product of the human articulation and constitution (where humanity as such appears as a sufficient condition for existence of such an image of the universe). The fact that the natural background of the universe is necessary for the human existence is an articulated and constituted fact, brought to light post-factum through scientific research whose possibility is based in the human intellectual capacities which are not causally implanted in the physical necessities.

Recapitulating the final point, one can approach cosmology within the enquiry of its relation to theology not from the point of view of that which it claims as a matter of fact (leaving this to the proper scientific cosmology), not from a point of numerous views of the universe from the historical past to its postmodern grand narratives (including numerous popular books), but as an ever present modus of the human existential activity which is always directed to the future (being indeed a 
cosmogonic process of world-building). Seen in this way, cosmology as aiming to explicate the sense of the universe, in particular its origin, forcefully demonstrates that the origin of the universe forms the telos of cosmological explanation and thus, by its constituted essence, is situated in the future of humanity (as an example one can point to a famous physicist J. A. Wheeler, who asserted, for example, that the Big Bang is a shorthand notion of that which is constituted through a scientific research at present; see his book [9]). In spite of a seemingly paradoxical nature of this conclusion, it can receive a philosophical justification as the working of the formal teleology in the cosmological research which originates in the human cognitive faculties [10]. If the whole of cosmological research related to tracing down the origins of the evolving universe can be seen as a certain formally teleological activity, then the entrance of a theological dimension in the issue of "cosmology and theology" can be seen not straightforwardly as if scientific views are brought into correlation with the experience of God (which would have no sense anyway) but as bringing into correlation of two different types of the intrinsically teleological contemplation of the universe whose purposes, in spite of their differences in content, have a common origin in the human condition.

Theology never implied an accomplished cosmological synthesis because theology dealt with the human situation in the created world in communion with God. However, theology together with philosophy engages with the cosmological discourse when men experience emotional and spiritual predicaments in appropriating the findings of cosmology. This happens when humanity has to face its radical physical insignificance in the universe and its contingency upon physical factors which are beyond man's control. Whether one implies a single universe related to what we observe or multiverse, man's physical position in the cosmos can be described in terms of cosmic homelessness (M. Heidegger), non-attunement (J.-F. Lyotard), restestlessness (S. Frank), or saying shortly as deprived of sense and value. This is confirmed not only through the modern estimate of the visible universe's size in terms of 92 billions of light years at whose background the habitable zone of the planet Earth with its atmosphere of 10 kilometres high seems to be infinitely small, but, in fact, through a fundamental chaining of humanity to the planet Earth. Indeed, as recent scientific result assert, any perspective of expansion of humanity in space seems to be bleak because of the over-penetrating cosmic ionising radiation contradicting to any existence of life. Geocentrism becomes for humanity not an option, but as the imperative (it does not imply that humanity has to deny existence of life and intelligence beyond Earth, the question is about the possibility of being displaced in space). And it is in the background of this inevitability of geocentrism that all cosmological discoveries and estimates of the size and the age of the universe seem to be very depressing if humanity treats itself only in physical terms. Cosmology in this sense explicates well the predicaments of the human condition. It provides a profound account of what humanity has achieved in a short historical period in terms of understanding of the outer cosmos, but, as such, cosmology does elucidate the sense of the human existence only apophatically: it describes the extent of how the universe is hostile to humanity.

Cosmology outlines the necessary conditions for existence of humanity, but it leaves untouched any question on the contingent facticity of and the sense in these conditions. Certainly this is not cosmology's business to deal with this issue. But, any cosmologist must remember their discipline exists only because there are human beings endowed with an intellect and whose existence is elucidated by this cosmology only to a "half." Thus cosmology exists in the unclarified conditions of its own possibility. To clarify the latter, it is enough to pose a question of how men 
with the $20 \mathrm{~cm}$ of their brains are capable of producing an instantaneous synthesis of the practically infinite universe. Philosophically, once can rephrase this question as to where from humanity has access to the idea of infinity? It is only in the background of this innate idea that humanity is capable of sensing its physical incommensurability with the universe, its homelessness, nonattunement and restlessness. History shows that one can survive on this planet without ever thinking about the cosmic place just imitating an animal "freedom" from enquiring into the sense of existence. It is here that one observes a certain reversal of the situation with the cosmic place: the human obsession with its place in the universe transforms into the question of why this very obsession is given to humanity in the very fact of its existence. In other words, where the very possibility of cosmology comes from and what is its purpose in view of its depressive (but obviously scientifically dispassionate and objective) findings?

All these questions are related to the realm of the human affairs by treating cosmology as one of them. But the human affairs take place within the order of history which is a subject matter of theology and here cosmology naturally meets theology. Cosmology receives its explication from within the human condition and human history, that is, existentially. One finds the questions of the universe as a whole, of its origin, its suitability for the human existence etc. as grounded in the basic concern of humanity about the sense of its own existence. By doing cosmology humanity attempts to achieve existential goals functioning in its psyche in rubrics of faith in humanity' destiny as it is portrayed from within the order of sacred history.

How then a vision of such existential goals cascades towards the vision of the order of the cosmos? The answer to this question contributes to the question on the relevance of theology to cosmology.

\section{Results and discussion.}

Modern Cosmology and Theology: hot issues.

1. The inseparability of cosmology and theology.

Cosmology and theology are inseparable in a trivial philosophical sense because they are both are related to the realm of human activity. However, more specifically, the very possibility of theology is determined by the possibility of existence of the incarnate human persons, that is by the necessary physical and biological conditions for the existence of theologians, the conditions which are ultimately cosmological. From here one concludes that any theological proposition implicitly contains truth about the world as such. The argument from cosmology to theology flows in a similar manner: cosmology studies the universe without clarifying the sense of the sufficient conditions responsible not only for the outcomes of the physical laws in order to have a given display of the universe, but also for the very possibility of knowledge and explication of the universe by human persons. Although theology does not explain these facts, it interprets them by pointing out that only human beings have a rational capacity of studying and articulating the universe associated with their special creation in Divine Image. Thus theology is implicitly present in all cosmological formulae, so that cosmology as such contributes to the explication of the special position of humanity in the universe.

2. Fine Tuning, Anthropic Principle, fitness of the universe for life.

The Anthropic Cosmological Principle (AP) explicates that the necessary physical conditions for the existence of humanity are finely balanced (fine-tuning) in the evolutionary universe leading to the possibility of life on Earth [11]. Thus AP contributes further to the articulation of 
consubstantiality of humanity to the universe. Theological anthropology accentuates this point through its stance of the microcosmic and meditational position of humanity in creation thus mimicking in its constitution the structure of the visible universe. Cosmology confirms that humanity indeed recapitulates the visible universe (only $4 \%$ of the overall matter) but its actual presence in the universe is radically insignificant in physical terms in spite of theological claims of humanity's centrality as being the centre of disclosure and manifestation of the universe. The theological claim for humanity to be responsible for the transfiguration of the universe and overcoming the moral division between it and the creator seems to be unclear, if it is treated literally, in view of the modern cosmological stance on insignificance of the human position in space and time. Humanity through its theoretical research could be considered as mediating between the visible and invisible (noetic) universe on the epistemological level. This propensity is not trivial natural fact and cannot be explicated philosophically. Yet, theology can interpret it Christologically by referring to the archetypical image of the incarnate Christ who, by assuming human flesh in space and time, remained the creator of the universe, thus by being present in it hypostatically.

3. The unknowability of the universe and apophatic cosmology?

In spite of the fact that, according to the Anthropic Principle humanity is consubstantial to the visible universe, the universe in its bulk content remains unknowable because, according to modern cosmology, it consist of $96 \%$ of Dark Matter and Dark Energy which do not physically interact with those constituents from the optically and experimentally visible part of the universe, including human bodies (its existence is presupposed on logical grounds in order to keep theory consistent, but there are no empirical clues what kind of matter it is). In other words, humanity is consubstantial only to $4 \%$ of the material stuff of the universe thus loosing its title of the physical microcosm in relation to the universe as a whole. Then the question is: does physical cosmology amend the philosophical and theological reading of man as microcosm, relegating its microcosmic function only to an epistemological sphere thus positioning the finite and nomistically limited human beings at the centre of disclosure and manifestation of the universe? In this case, does the $96 \%$ of the non-consubstantial and invisible matter appear only as theoretical constructs for the purpose of a coherent cosmological explanation?

Then it seems reasonable to conjecture that since the universe's content remains unknowable, its description represents an open-ended hermeneutics, whose present scientific episode contributes to the endless narrative about it. One then makes a comparison between the apophaticism in theology where all definitions and narrations of the Divine never exhaust the sense of what is signified by them, with the apophaticism in cosmology, claiming that the ultimate nature of the universe is inaccessible to the human reason in the conditions of its embodiment. Theologically, such an observation contributes to an argument that the universe is unknowable to the same extent as unknowable its Creator. This conclusion is similar to another theological claim of man's inability to know himself as being a Divine Image of the incomprehensible God.

4. Multiple universes.

The "fine-tuning" issue relates to the very low probability of the initial conditions of the universe, if one assumes (in any possible sense) the potential existence of the ensemble of the universes, and hence a choice of that one out of them which represents our universe [12]. The major problem with the hypothesis of the multiverse is its radically non-empirical status and hence with its testability entailing a doubt in a scientific nature of this hypothesis [13]. The claimed 
proposals for scientific tests of the physical existence of a multiverse most of which rely on probability concepts are doubtful because it seems that one cannot use probability arguments in cosmology when only one universe exists. Probability arguments cannot prove a multiverse exists, they can only prove the self-consistency of multiverse proposals as such. Yet some cosmologists, in order to avoid any appeal to the idea of creation of the universe and its creator, prefer the multiverse model by simply ontologizing its construct in a naively realistic fashion. From a theological point of view, the perennial issue of the contingent facticity of the multiverse itself (as a new type of the highly undifferentiated "substance") remains untouched by any of its models so that in no way the multiverse hypothesis can replace or "explain" creatio ex nihilo. Yet, from the same theological point of view the idea of the multiverse can represent an interest if considered in a platonic sense: God created many intelligible universes, but only one or some of them have received an embodied physical existence.

5. How much of life is in the universe: Search for Extraterrestrial Intelligence (SETI), exoplanets, multiple incarnations.

Recent discoveries of exoplanets stimulated a new wave of the search for extraterrestrial intelligence in our galaxy assuming that the necessary physical and biological conditions for life are fulfilled on these planets. Then the question of existence of intelligent sentient beings on other planets receives many theological overtones:

1) Do the similar necessary conditions of existence of life entail the same sufficient conditions leading to appearance of intelligent beings similar to those of humanity?

2) In what sense can one speak of the other intelligent beings if they are not in the Divine Image: do we have an epistemological access to them.

3) Do potential intelligent beings experience a similar to us regression in communion with the creator and hence need salvation?

4) Can multiple incarnations happen in the universe or a single Incarnation on Earth is enough in order its effects to be communicated by humans to other inhabited worlds?

5) Do we soteriologically need to know of and contact with those potential beings in the conditions when the sense of our own world is obscured by the garments of skin?

6) How the issue of SETI can be disentangled from the theologically expressed concern for the cosmos at large being devoid of grace and potentially threatening by being usurped by fallen angels?

In view of the NASA's recent discoveries of the practical impossibility of cosmic travels because of the high exposure to the ionising radiation by fast cosmic particles, the planet Earth remains the only place for humanity to exist which puts in doubt any phantasies of the human expansion in the universe. Hence, can the discovery of exoplanets in conjunction with the impossibility of the remote travelling in space, as well as the advance in the SETI, explicate further the sense of a theological claim for the centrality of Earth and the geocentric uniqueness of the Incarnation.

6. The origin of the universe and creatio ex nihilo.

The issue of origination of the universe represents a major challenge for scientific cosmology because of its lack of testability. Here physical theories reach their limits if testability is regarded as being an essential attribute of physics. Theories of creation of the universe are not testable and cosmological observations provide very weak limits on conditions immediately after creation 
because the inflationary phase of expansion wipes out most memory of that which preceded it. Alleged 'explanations' of creation rely on extrapolating some aspects of tested physics to situations where tests are not possible. Usually they employ physical theories (such as Quantum Field Theory, for example) held to be applicable in situations before space and time existed, in spite of the fact that their usual formulation assumes that space and time do exist. So the major issue here is, what features of cosmology (physics) depend on the existence of the universe, and which transcend it? Only those that transcend it can feature in theories of how the universe came into being. This raises a question of how to understand the transcendent features of theories in an ontological sense. What kind of existence is assigned to the theoretically constituted origin of the universe: is it indeed physical, or just mathematical (platonic), or intersubjective (remaining a regulative idea in a Kantian sense)? In the latter case one has to deal with the issue of how philosophical and theological rigor can enter into the data verification and analysis in cosmology of the early universe and what will be the ultimate quality of the argument: metaphysical or scientific. Can top-down explications of the origin of the universe be considered as a legitimate mental causation? In addition to this, can one enquire whether these transcendent features of theories based on mental causation point towards the fact that scientific theories of the early universe 'detect' the presence of the Divine? (see more in $[14,15]$ ).

In spite of all the issues raised above, the discourse of origination of the universe in a singular state (Big Bang) which is traditionally related to the theologically understood creatio ex nihilo, can be considered as the most developed in the context of the dialogue with theology. Theology provided lots of writings on creation of the universe out of nothing, but it was never concerned with the specifically cosmological aspects of creation because it never aimed to produce any accomplished cosmology. Any co-relation of theological ideas on creation with the modern cosmological narrative would be considered not only as anachronistic, but logically purposeless because of the historically contingent means of comparing of the two narratives. The essential feature of the patristic narrative of creation is to place it in the logic of transfiguration of the universe and human deification enabled through the Incarnation of Christ. In this sense the whole cosmology of the Fathers is through and through Christocentric thus approaching creation through its major motive - the Incarnation. Correspondingly the only possible novelty in appropriation of modern cosmology of the early universe by theology would be by treating the origination of the universe as related to the motive of the Incarnation, that is, by linking the initial conditions of the universe to the necessary conditions for the Incarnation (and hence the existence of humanity).

There are two other issues from theology of creation that can be relevant to the modern cosmological views of origination of the universe: 1) the dual structure of the created realm: the empirical and intelligible (theoretical models of the visible universe) as the constitutive element of creatio ex nihilo; 2) the contingency of creation expressed through the perennial question of "why not sooner?" of creation. The 1) is related to the issue of the importance of the intelligible creation/causation (platonic worlds, multiverse, mathematical objects) in the overall cosmological picture; the 2) is related to the age of the universe (either biblical, or scientifically stated) which refers the issue to the contingency of the initial conditions of the universe (as the transcendent feature of cosmological theories) and hence theologically to the unknown will and wisdom of the creator. Then cosmological models of origination of the universe can be treated as contributing to the open-ended hermeneutics of the contingent facticity of the universe thus expressing the 
ultimate unknowability of its origin related to the impossibility of constructing the causal principle of the world.

\section{Consciousness and the universe.}

Physics in its classical form, when it works in the natural attitude and disregards the functioning of that subjectivity which predicates the physical world, cannot incorporate consciousness in its scope. The word 'classical' is used here not in order to contrapose quantum physics to that which is traditionally called 'classical physics'. This word is used in a philosophical sense related to that particular phenomenality with which physics deals (namely the phenomenality of objects), that is, with that which is allegedly objective and independent of the human insight. There are many speculations and a hope that Quantum Physics will change this approach to reality and bring onboard the presence of an enquiring subject. It suffices to mention all famous discussions on the role of the observer within the Copenhagen interpretation of Quantum mechanics. However all these discussions do not change anything in the understanding of the sense of humanity in the universe as embodied hypostatic creatures with their private sense of existence (expressed in 1st person) which is not describable by any possible science. This is the reason why physics until now attempts to banish any enquiry into the sense of personal consciousness by insisting on studying the objective world. This tendency seems to be strange, in particular when the same physics claims to seek for the Theory of Everything which must include consciousness in the universe by definition. Cosmology, at first glance, contributes to the diminution of humanity in the universe by proving its utter insignificance on the physical scale. Correspondingly the status of the embodied consciousness in the universe seems to be negligible and incidental. However this observation enters a direct contradiction with the fact that this very observation is possible only because humanity is epistemologically central in the universe to the extent that the overall picture of the evolving universe is the product of humanity's mental activity.

The very fact of existence of the universe is manifested through the fact of existence of humanity. Hence the very possibility of existence of the universe in a humanly articulated form is possible only because of the existence of human intelligent beings (theologically made in the divine image). Then one can conclude that the human intelligence may be a fundamental rather than incidental feature of the universe, implicitly present in the very definition of the universe as the sum total of being. In this case any old-fashion models of "God of the Gaps" on the one hand, and any claim of the absolute (God-given) truth about the world, on the other hand, become relevant only in the sense that these models are implanted into the open-ended hermeneutics of the human condition from within which the disclosure and manifestation of the universe is going on together with the advance in experience of the Divine. Saying differently, if God is supposed to be everywhere in the universe, then one could expect cosmology to reveal him in some specific ways which are encoded in the human approximations for truth. Cosmology here must be compatible with a direct religious experience of communion with the Divine, because this experience is in the same universe. One implies the compatible hermeneutics of existence in cosmology and theology which is in a constant dialogue.

Then theological and cosmological hermeneutics of existence can be considered phenomenologically as constitutive of humanity as the centre of disclosure and manifestation of the universe. In this case the question of explanation of consciousness by some scientific and philosophical means looses its sense and acquires a different status, namely as that which manifests 
existence as such, including either theological or scientific forms. In this case one stops looking for the ultimate foundation and origin of the hypostatic consciousness in the universe by taking as this foundation not the hypothetical mechanism of the transition from the animal consciousness to that one of Homo Sapiens, for example, but by studying consciousness' evolution through its acquisition of the world and hence its (allegedly metaphysical) explanation of its origin through constructing the origin of the universe. In no way, however, such an 'explanation' will have a theoretical, ontological sense: it will provide us only with a regulative approach to the goal of our explanation, that is consciousness itself. Consciousness will always be encoded in theories and explanations of the universe but it will never be 'seen' as an object, as that which can be defined in terms of substance and its variations. It will always remain a transcendental condition of disclosure and manifestation of the universe, that condition which humanity receives together with the gift of life. In this phenomenological view cosmology acquires the sense of a particular form of the human subjectivity dealing with the conditions of its physical existence. It becomes a different experience of existence, when consciousness has to balance its internal sense of existence as a private person with that other in the background of which this privacy experiences its being through communion with the Giver of life. Then any cosmological enquiry, in a phenomenological sense, can be considered as contributing to the experience of the Divine as the giver of the physical and intellectual possibility of this enquiry.

Conclusion. On the basis of the methods applied to the hot issues in the dialogue between cosmology and theology one concludes that the dialogue between cosmology and theology is an open-ended enterprise related to the fundamentally concealed origins of humanity and universe. The difference is hermeneutics of the universe does not create any contradiction or tension but reflects a dualistic position of humanity in the universe, being an insignificant part of it and at the same time its centre of disclosure and manifestation.

\section{REFERENCES}

1. Carr, B. (2017), "Black Holes, Cosmology and the Passage of Time: Three Problems and the Limits of Science", The Philosophy of Cosmology, in Chamcham, K., et al. (eds.), Cambridge Univ. Press, Cambridge, UK, pp. 40-65. DOI: https://doi.org/10.1017/9781316535783.003.

2. Ellis, G.F.R. (2017), "The Domain of Cosmology and the Testing of Cosmological Theories", The Philosophy of Cosmology, in Chamcham, K., et al. (eds.), Cambridge Univ. Press, Cambridge, UK, pp. 339. DOI: https://doi.org/10.1017/9781316535783.002.

3. Yannaras, C. (2004), Postmodern Metaphysics, Transl. by Russel, N., Holy Cross Orthodox Press, Brookline, USA.

4. Peters, T., Hewlett, M., Moritz, J.M. and Russell, R.J. (eds.) (2018), Astrotheology. Science and Theology Meet Extraterrestrial Life, Cascade, Eugene, USA.

5. Disney, M.J. (2000), "The Case Against Cosmology", General Relativity and Gravitation, vol. 32, pp. 1125-1134. DOI: https://doi.org/10.1023/A:1001981929727.

6. Cornwell, J. (2004), "Hawking's quest: a search without end", The Tablet (27 March 2004), pp. 4-5.

7. Krauss, L.M. (2012), A Universe from Nothing, Free Press, NY, USA.

8. Stenger, V. (2008), God the Failed Hypothesis: How Science Shows that God Does not Exist, Prometheus Books, NY, USA.

9. Wheeler, J.A. (1996), At Home in the Universe, American Institute of Physics, NY, USA.

10. Immanuel Kant, Critique of Judgement (1951), Trans. by Bernard, J.H., Hafner, NY, USA.

11. Barrow, J.D. and Tipler, F.J. (1986), Anthropic Cosmological Principle, Clarendon Press, Oxford, UK. 
12. Carr, B.J. (ed.) (2007), Universe or Multiverse?, Cambridge Univ. Press, Cambridge, UK.

13. Ellis, G.F.R. (2011), “Does the Multiverse Really Exist?”, Scientific American, pp. 38-43.

14. McMullin, E. (1981), "How should cosmology relate to theology?", The Sciences and Theology in the Twentieth Century, in Peacocke, A.R. (ed.), Oriel Press, London, UK, pp. 17-57.

15. McMullin, E. (1998), "Is philosophy relevant to cosmology?", Modern Cosmology and Philosophy, in Leslie, J. (ed.), Prometheus, NY, USA, pp. 46-82.

\section{Information about the authors.}

Alexei V. Nesteruk - Dr. Sci. (Philosophy) (2019), Visiting Research Lecturer at the University of Portsmouth, Lion Gate Bld, Portsmouth, P01 3HF, UK. Associate Professor at the Inter-University Centre on Education in History and Philosophy of Science, State Marine Technical University, 3 Lotsmanskaya str., St Petersburg 190121, Russia. The author of 116 scientific publications. Areas of expertise: cosmology, philosophy of science, the dialogue between science and theology. ORCID: https://orcid.org/0000-0001-6318-7907.E-mail: alexei.nesteruk@port.ac.uk

Aleksandr V. Soldatov - Dr. Sci. (Philosophy) (1991), Professor (1992), Head of the Department of Philosophy and Sociology, State Marine Technical University, 3 Lotsmanskaya str., St Petersburg 190121, Russia. The author of 205 scientific publications. Areas of expertise: philosophy of science, philosophy of religion, sociology of science. ORCID: https://orcid.org/00000001-5548-1735. E-mail: soldatov2012@yandex.ru

\section{СПИСОК ЛИТЕРАТУРЫ}

1. Carr B. Black Holes, Cosmology and the Passage of Time: Three Problems and the Limits of Science // The Philosophy of Cosmology / in K. Chamcham et al. (eds.). Cambridge: Cambridge Univ. Press, 2017. P. 40-65. DOI: https://doi.org/10.1017/9781316535783.003.

2. Ellis G. F. R. The Domain of Cosmology and the Testing of Cosmological Theories // The Philosophy of Cosmology / in K. Chamcham et al. (eds.). Cambridge: Cambridge Univ. Press, 2017. P. 339. DOI: https://doi.org/10.1017/9781316535783.002.

3. Yannaras C. Postmodern Metaphysics / transl. by N. Russel. Brookline: Holy Cross Orthodox Press, 2004.

4. Astrotheology. Science and Theology Meet Extraterrestrial Life / in T. Peters, M. Hewlett, J. M. Moritz, R. J. Russell (eds.). Eugene: Cascade, 2018.

5. Disney M. J. The Case Against Cosmology // General Relativity and Gravitation. 2000. Vol. 32. P. 1125-1134. DOI: https://doi.org/10.1023/A:1001981929727.

6. Cornwell J. Hawking's quest: a search without end // The Tablet. 27 March 2004. P. 4-5.

7. Krauss L. M. A Universe from Nothing, NY: Free Press, 2012.

8. Stenger V. God the Failed Hypothesis: How Science Shows that God Does not Exist. NY: Prometheus Books, 2008,

9. Wheeler J. A. At Home in the Universe, NY: American Institute of Physics, 1996.

10. Immanuel Kant, Critique of Judgement / trans. by J. H. Bernard. NY: Hafner, 1951.

11. Barrow J. D., Tipler F. J. Anthropic Cosmological Principle. Oxford: Clarendon Press, 1986.

12. Universe or Multiverse? / in B. J. Carr (ed.). Cambridge: Cambridge Univ. Press, 2007.

13. Ellis G. F. R. Does the Multiverse Really Exist? // Scientific American, 2011. P. 38-43.

14. McMullin E. How should cosmology relate to theology? // The Sciences and Theology in the Twentieth Century / in A. R. Peacocke (ed.). London: Oriel Press, 1981. P. 17-57.

15. McMullin E. Is philosophy relevant to cosmology? // Modern Cosmology and Philosophy / in J. Leslie (ed.). NY: Prometheus, 1998. P. 46-82. 


\section{Информация об авторах.}

Нестерук Алексей Всеволодович - доктор философских наук (2019), научный сотрудник университета Портсмута, Лайон Гэйт корп., Портсмут, PO1 3TR, Великобритания. Доцент межвузовского центра по образованию в области истории и философии науки при Санкт-Петербургском государственном морском техническом университете, Лоцманская ул., д. 3, Санкт-Петербург, 190121, Россия. Автор 116 научных публикаций. Сфера научных интересов: космология, философия науки, диалог между наукой и богословием. ORCID: https://orcid.org/0000-0001-6318-7907. E-mail: alexei.nesteruk@port.ac.uk

Солдатов Александр Васильевич - доктор философских наук (1991), профессор (1992), заведующий кафедрой философии и социологии Санкт-Петербургского государственного морского технического университета, Лоцманская ул., д. 3, Санкт-Петербург, 190121, Россия. Автор 205 научных публикаций. Сфера научных интересов: философия науки, философия религии, социология науки. ORCID: https://orcid.org/0000-0001-55481735. E-mail: soldatov2012@yandex.ru 